\title{
The influence of social media marketing, product innovation and market orientation on Indone- sian SMEs marketing performance
}

\author{
Khamaludin $^{a^{*}}$, Syahriani Syama, Febri Rismaningsih ${ }^{a}$, Lusiani ${ }^{\mathrm{b}}$, Lily Arliantia ${ }^{\mathrm{a}}$, Ahmad Fajar \\ Herlani $^{a}$, Mochammad Fahlevi ${ }^{\text {c }}$, Raendhi Rahmadia ${ }^{a}$, Vina Septiana Windyasari ${ }^{a}$ and Fita \\ Widiyatun $^{\mathrm{d}}$
}

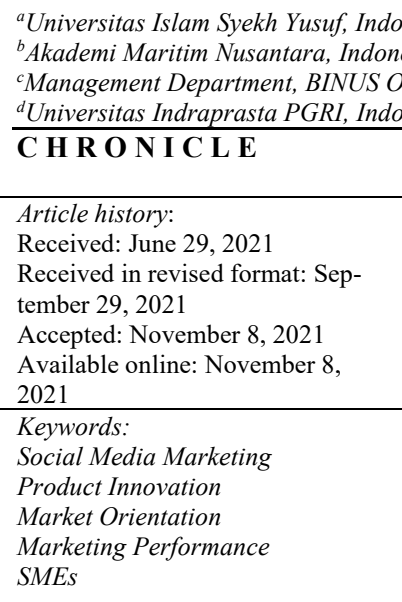

\section{Introduction}

The development of information technology today makes people no longer have a problem with distance limits, space and time. Information technology gave birth to the internet, the internet offers many benefits for SMEs to increase their product marketing. According to Pramono et al. (2021) the internet provides the benefits of increasing the opportunity for SMEs to collaborate with other entrepreneurs. One of the internet technologies that is growing rapidly and has great potential to encourage SME marketing is social media. Social media has the potential to connect many people easily and free of charge. There are many benefits of using social media in developing SMEs and they are one of the strong driving factors for SMEs to continue to use social media in order to develop their business, increase product sales, communicate with consumers, and develop a wider market network. Social media is very helpful as a liaison of information and communication from producers to consumers wherever they are and whatever the distance. Social Media has now become a trend in marketing communications. According to Haudi et al. (2021) social media is a group of Internet-based applications that build on the ideological and technological framework of Web2.0 and enable the creation of the exchange of information content from internet users. Web 2.0 is the basis for the formation of social media. According Djakasaputra et al. (2021) the growing trend on social media

* Corresponding author.

E-mail address: khamaludin@unis.ac.id (Khamaludin) 
currently are: twitter, Facebook, myspace, Youtube, Instagram, path, Whatsapp, line, etc. Given the importance of information on how to use social media for SMEs and benefits, it is necessary to conduct an observational study. According Wijaya et al. (2021), social media networks are a gateway for companies to profit and grow the ceramics industry. Companies are increasingly interested in using social media both for business purposes especially those that are part of their communications, marketing and recruitment. Social networking has become a daily practice in the lives of users in our society as well as SME entrepreneurs. This not only offers vast opportunities but also presents challenges significant for entrepreneurs. In this era of industrial revolution, the number of SMEs in Indonesia reached 64.19 million, Micro and Small Enterprises (SMEs) were dominant, namely 64.13 million $(99.92 \%)$ who felt the negative impact of the Covid-19 pandemic. Based on BPS data, the number of MSMEs reached 64.2 million units per 2020. Micro, Small and Medium Enterprises (MSMEs) contributed 60.3\% of the total Gross Domestic Product (GDP) and absorbed 97\% of the total workforce and 99\% of the total employment. Innovation is one of the most important competitive factors to achieve success where lately the business environment is always changing rapidly. The role of Micro, Small and Medium Enterprises (MSMEs) is very vital in encouraging the pace of national economic growth (Kristiyanti, 2012). Marketing innovation is an integral component of a company's success. Marketing innovation is more emphasized on the marketing performance of SMEs as competitiveness. Product innovation is very important to be carried out by a company with the aim of maintaining the value of product benefits for consumers. Marketing innovation and product innovation that can continuously improve innovative performance. Innovative performance can be improved through competitive advantage where competitive advantage can be created by innovating.

According to the Katadata Insight Center (KIC), based on a survey of 206 MSME actors in Banten, most SMEs (82.9\%) felt the negative impact of this pandemic and only 5.9\% experienced growth. This pandemic condition has even caused $63.9 \%$ of the affected MSMEs to experience a decline in turnover of more than $30 \%$. Only $3.8 \%$ of SMEs experienced an increase in turnover. According to Shaher et al. (2020) and Kristijono et al. (2020), 87.5 percent of SMEs were affected by the Covid-19 pandemic. Of this amount, around 93.2 percent of them were negatively affected on the sales side. According to BPS, Bappenas, and the World Bank, this pandemic has caused many SMEs to have difficulty paying off loans as well as paying electricity, gas, and employee salaries. Some of them even had to do layoffs. Other obstacles faced by SMEs include difficulty in obtaining raw materials, capital, declining customers, distribution and production constraints. Based on a preliminary survey of 41 SMEs, it was found that during the last two years data was obtained that there were $58 \%$ of SMEs that experienced a decrease in the number of goods produced with a percentage decline of around $50-60 \%$. There are $65 \%$ of SMEs experiencing a decrease in the number of goods sold with a percentage decline of around $60-80 \%$. There are $70 \%$ of SMEs experiencing a decline in income with a percentage decline of around $60-70 \%$. There are $68 \%$ of SMEs experiencing a decrease in the number of customers with a percentage decline of around $70-80 \%$. There are $58 \%$ of SMEs that experienced a decrease in the amount of capital with a percentage decline of around 30-50\%. According to "Digital Around The World 2019", in Indonesia alone there are more than 150 million people who use social media out of a total of 268 million population. They spend at least 3 hours and 26 minutes every day accessing social media for any purpose. According to statistical data, social media users in the world will reach 3.1 billion in 2021. This is one of the best reasons why SMEs should try to market through social media, namely because consumers spend most of their time on social media. The number of activities presents a great opportunity to reach consumers anywhere and anytime.

\section{Hypothesis Development}

\subsection{The relationship between social media and marketing Performance}

Research conducted by Affandi et al. (2020), Aji et al. (2020) stated that an increase in the Social media variable will encourage an increase in the Marketing Performance variable. According to research conducted by Affandi et al. (2020), Aji et al. (2020), Han et al. (1998), Hurley et al. (1998), Kristijono et al. (2020), Social media has a significant influence on the Marketing Performance variable. Social media theory will have a positive influence on increasing Marketing Performance. According to research conducted by Hurley et al. (1998) and Kristijono et al. (2020), an increase in Social media will increase in Marketing Performance. Based on theoretical studies and previous studies, the following hypotheses are formulated:

\section{Hypothesis 1: There is a positive influence between Social Media and Marketing Performance.}

\subsection{Relationship between Product Innovation and Marketing Performance}

Research results by Affandi et al. (2020), Aji et al. (2020), Han et al. (1998), Hurley et al. (1998) and Kristijono et al. (2020) state that Product Innovation has a positive influence on marketing performance. Product Innovation plays a major role in increasing marketing performance, which is in accordance with the statement according to Hurley et al. (1998), Kristijono et al. (2020) and the importance of Product Innovation will affect the effort required and ultimately can be seen from marketing performance. This study also supports research conducted by Hurley et al. (1998), Kristijono et al. (2020) who found that Product Innovation influences marketing performance. Based on theoretical studies and previous studies, the following hypotheses are formulated:

Hypothesis 2: There is a positive influence between Product Innovation and Marketing Performance. 
Market Orientation is one of the factors that affect employee performance. Research results from Purwanto et al. (2019) and Salimi et al. (2019) show that Market Orientation has a positive effect on marketing performance. While other studies also show the same thing that Market Orientation influences marketing performance (Nguyen et al., 2015; Purwanto et al., 2021; Purwanto et al., 2021; Purwanto et al., 2019; Salimi et al., 2019). According to Salimi et al. (2019), Market Orientation is a variable that affects market performance. Purwanto et al. (2021), Purwanto et al. (2019) and Salimi et al. (2019) explained that Market Orientation is a rational behavior to achieve the required goals in accordance with the expected conditions. Based on theoretical studies and previous studies, the following hypotheses are formulated:

Hypothesis 3: There is a positive influence between Market Orientation and Marketing Performance.

\section{Method}

This study uses quantitative methods and data analysis techniques are executed using Structural Equation Modeling Equation Modeling by SmartPLS 3.0 software. The sample selection method used is the snowball sampling method. Online questionnaires were sent to respondents as many as 320 SMEs in Banten Province, 300 returned the questionnaires and 20 questionnaires did not. Based on theoretical studies and previous studies, the following research model was developed:

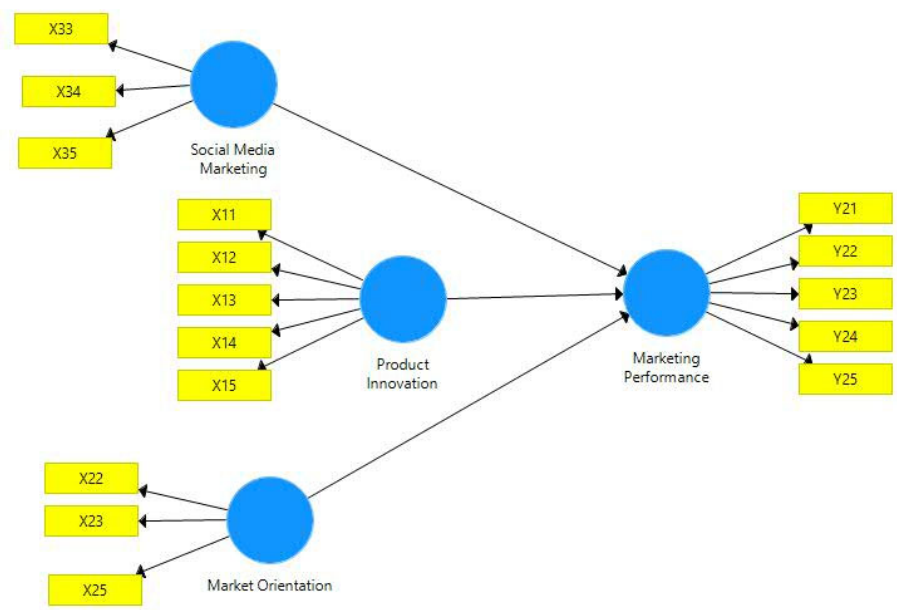

Fig. 1. Research Model

The stages of data processing in this research are validity testing with Cronbach's Alpha value indicator value $>0.7$, then validity testing with the criteria the loading factor value is $>0.7$, discriminant validity testing with AVE root value is $>0.50$, the value of the coefficient of determination ( $\mathrm{R}$ Square).

\section{Result and Discussion}

\subsection{Validity and Reliability testing}

Validity and reliability testing can be analyzed with SmartPLS. The validity of an indicator variable in measuring the latent variable can be assessed by looking at the value of the Loading Factor (LF). In general (rule of thumb), the value of the LF indicator 0.7 is said to be valid, but according to Purwanto et al. (2019) in the development of new indicators, the values of LF 0.5 and 0.6 are still acceptable for validity, even 0.4 is also tolerable. The consistency of the indicator variables in measuring the latent variables can be seen from the construct reliability and variance extracted values. If the value of construct reliability $>0.7$ and variant extracted $>0.5$, then it shows that the indicator variable is consistent (Purwanto et al., 2021). The composite reliability value of each indicator can be seen in Table 1 below.

Table 1

Reliability Testing

\begin{tabular}{lcc}
\hline Variables & Cronbach's Alpha & Composite Reliability \\
Social media & 0.821 & 0.923 \\
Product Innovation & 0.923 & 0.924 \\
Market Orientation & 0.912 & 0.835 \\
Marketing Performance & 0.834 & 0.912 \\
\hline
\end{tabular}


The results of the reliability test of Table 1 show that the statements or items of the four variables are all reliable. All these variables get a composite reliability value greater than 0.7 so they are considered reliable. Table 1 shows that all existing variables have met the requirements of composite reliability since the results obtained have met the recommended number, which is greater than 0.7 and is considered that all statements or items of the four variables studied are reliable. Reliability according to Purwanto et al. (2021) shows the level of consistency and the stability of measuring instruments or research instruments in measuring a concept or construct. Composite reliability measures the true reliability value of a variable, while Cronbach alpha measures the lowest value of the reliability of a variable so that the composite reliability value is always higher than Cronbach alpha. To be said to be a reliable construct, the Cronbach Alpha value must be $>0.6$ and the Composite Reliability value must be $>0.7$.

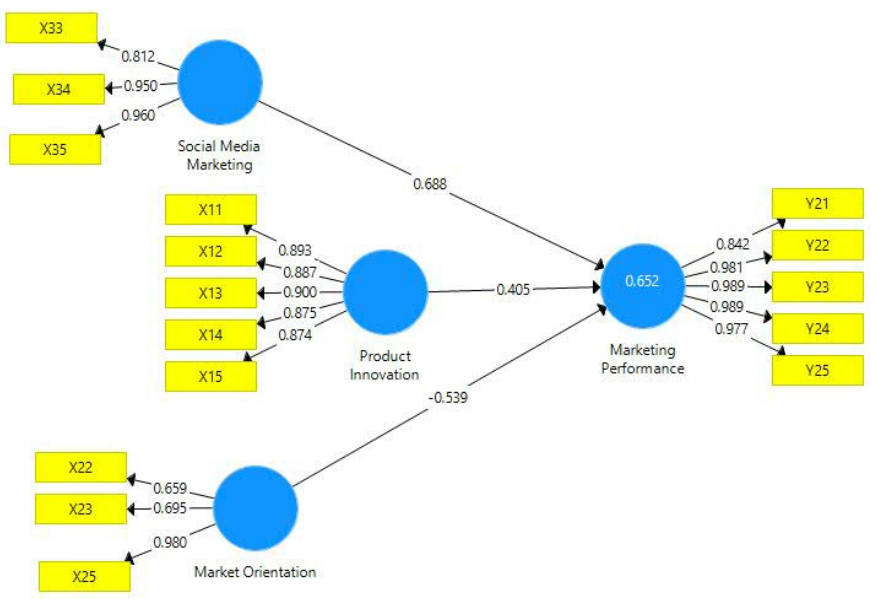

Fig. 2. Convergent Validity

\subsection{Discriminant validity}

To evaluate discriminant validity, we may look for the average variance extracted (AVE) method for each construct or latent variable. The model has better discriminant validity if the AVE square for each construct is greater than the correlation between the two constructs in the model. The AVE value describes the variance or diversity of manifest variables that can be owned by the latent construct. Purwanto et al. (2019) recommend the use of AVE for a criterion in assessing Convergent Validity. An AVE value of at least 0.5 indicates a good Convergent Validity measure. That is, the latent variable can explain the average of more than half the variance of the indicators

\section{Table 2}

Average variance extracted (AVE)

\begin{tabular}{ll}
\hline Variables & AVE \\
\hline Social media & 0.823 \\
Product Innovation & 0.622 \\
Market Orientation & 0.911 \\
Marketing Performance & 0.921 \\
\hline
\end{tabular}

Table 3

R-square adjusted

\begin{tabular}{lc}
\hline Variables & R-square adjusted \\
\hline Marketing Performance & 0.652 \\
\hline
\end{tabular}

In Table 3 it can be explained that the adjusted $\mathrm{R}^{2}$ value of the independent variables Social media marketing, Product Innovation and market orientation to the dependent variable Marketing Performance is 0.652 . This value is categorized as strong. The independent variables of Social media, Product Innovation and market orientation contributed to the dependent variable Marketing Performance of $65.2 \%$ while the remaining $35.8 \%$ was influenced by other variables not discussed in this study. 


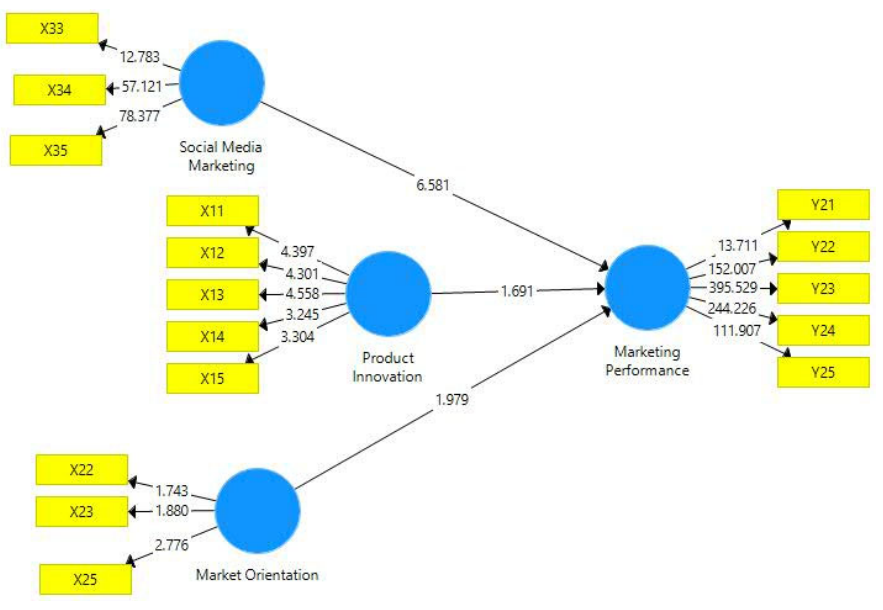

Fig. 3. Hypotheses Testing

\subsection{Hypothesis test}

According to Purwanto et al. (2021), testing the hypothesis can be executed by using Partial Least Square (PLS) analysis technique which is operated through Smart PLS 3 software. Hypothesis testing here, was conducted to determine the effect of independent variables on dependent variable. The value of $t$ count $(\mathrm{CR})>1.96$ or probability $(\mathrm{p})<0.05$ means that all independent variables influence the dependent variable.

\section{Table 4}

Hypotheses Testing for Direct Effect

\begin{tabular}{lcc}
\hline Hypotheses & P - Value & Result \\
\hline Social media $\rightarrow$ SMEs Marketing Performance & 0.011 & Significant \\
Product Innovation $\rightarrow$ SMEs Marketing Performance & 0.031 & Significant \\
Market Orientation $\rightarrow$ SMEs Marketing Performance & 0.012 & Significant \\
\hline
\end{tabular}

\section{Relationship between Social media and Marketing Performance}

Based on the results of data analysis using SmartPLS we have obtained a p-value $0.011<0.050$ and it can be concluded that Social media has a significant effect on Marketing Performance. In other words, increasing social media variables will have a significant effect on increasing Marketing Performance variables and vice versa. These results are in line with the research conducted by Nguyen et al. (2015), Purwanto et al. (2021), Purwanto et al. (2021), Purwanto et al. (2019) and Salimi et al. (2019), which state that social media has a positive and significant effect on Marketing Performance. Marketing with technology media that is easy to learn and apply by SMEs to expand traditional marketing functions, can contribute to product development using different social media such as Facebook. According to Salimi et al. (2019), digital marketing with social media can concentrate on all traditional marketing which states that marketing is like "interactive marketing", "one-to-one marketing" and "e-marketing" are closely related to "digital marketing". According to Nguyen et al. (2015), Purwanto et al. (2021), in the digital era, technological developments occur an evolution in media technology, or people also often call it online media or people are more familiar with calling it the term internet, where media is certainly familiar since nothing has matched the growth in the number of users.

\section{Relationship between Product Innovation and Marketing Performance}

Based on the results of data analysis using SmartPLS we have obtained a p-value of $0.003<0.050$ and it can be concluded that Product Innovation has some significant effect on Marketing Performance, in other words, an increase in the Product Innovation variable will have an insignificant effect on increasing the Marketing Performance variable and vise versa. These results are also in line with the research conducted by Affandi et al. (2020), Aji et al. (2020), Han et al. (1998), Hurley et al. (1998), Kristijono et al. (2020) which states that Product Innovation has a positive and significant impact on Marketing Performance.

According to Hurley et al. (1998) and Kristijono et al. (2020), innovation ability is the ability to accept and implement new ideas, processes, products and services and it is one of the main resources that drive the company's success in the market. The capability of innovation enables the company to apply the technological innovations needed to develop new products and fulfill the needs as well as one of the strategies to survive in the competition. The results of this study support the results of research conducted by Kristijono et al. (2020) and Hurley et al. (1998), and they state that marketing innovation is a component of the company's success. Innovation relies on the marketing performance of SMEs as competitiveness. Product and service 
development are carried out by SMEs to meet customer needs and focus on innovative performance. SMEs are facing marketbased innovation, so this requires SMEs to introduce better marketing innovations. Then there is a positive effect of marketing innovation on the innovative performance of SMEs. According to Affandi et al. (2020) innovation requires a lot of effort and achieving innovative performance requires great sacrifices. Good innovative performance can start with marketing innovations that are slowly implemented in the process.

\section{Relationship between Market Orientation and Marketing Performance}

Based on the results of data analysis using SmartPLS we have obtained a p-value of $0.012<0.050$ and it can be concluded that Market Orientation has a significant effect on Marketing Performance, which means an increase in the Market Orientation variable will have a significant effect on increasing the Marketing Performance variable and a decrease in the Market Orientation variable will have a significant effect on decreasing the Marketing. These results are not in line with the research conducted by Affandi et al. (2020), Aji et al. (2020), Han et al. (1998), Hurley et al. (1998), Kristijono et al. (2020) which indicate that Market Orientation has a positive and significant effect on Marketing Performance. Marketing capabilities include the ability to build and differentiate products and services from competitors with product innovation, customer-oriented, competitor-oriented and the capacity to apply knowledge, skills, and coordination of internal resources for market-related business needs. MO can identify the necessary conditions and the basis for business development as marketing capabilities and marketing strategies that are oriented to needs as business opportunities and challenges.

According Purba et al. (2021), benefits of using social media in developing SMEs are one of the strong driving factors for SMEs to continue to use social media to develop their business, increase product sales, communicate with consumers, and develop a wider market network. Social media is one of the media that facilitates interactive communication between entrepreneurs and anyone, including consumers, and various interested parties, whenever and wherever. Social media is very helpful as a liaison of information and communication from producers to consumers wherever they are and whatever the distance. One of the potentials that can be utilized is information technology. The current development of information technology makes people no longer worry about the limits of distance, space and time. Information technology gave birth to the internet, the internet offers many benefits for SMEs to increase their product marketing. In addition, the internet also provides the benefit of increasing the opportunity for SMEs to collaborate with other entrepreneurs. The internet technology is growing rapidly and has the potential to encourage SME marketing is social media. Social media has the potential to connect people easily and for free. Social Media has now become a trend in marketing communications.

According to Prahiawan et al. (2021) and Thongsri and Chang (2019), the importance of Small and Medium Enterprises (SMEs) utilizing the existence of social media is to improve the sales performance. SMEs try to utilize social media to reduce the distance, space and time, which leads to lower prices. SMEs do not need a large space to showcase/display their products. Besides, distance is also not considered as a barrier for sending goods, since there are already many courier-service companies to deliver goods by low prices and fast to consumers. Marketing can reach worldwide and labor can also be utilized effectively and efficiently. Therefore, SMEs, especially in Indonesia, are encouraged to promote and sell their products through social media. According to Purba et al. (2021) entrepreneurs use social media as a marketing tool since this tool can build a strong support network which is important for business growth. These supporters keep bringing customers/business for SME entrepreneurs by referring them to other people. Social media helps create long term relationships between businesses and customers. However, there are some issues related to social media such as lack of consensus on how it implements various activities since the platform and technology are dynamic and there is no clear guidance for businesses on how to take advantage of them. SMEs maintain their innovative performance on new products and services and improve the quality of goods so that changes that occur in innovation affect marketing performance targets.

Social media users in SMEs usually access their accounts to find entertainment and the latest information. They are less receptive when exposed to advertisements directly. But that does not mean we cannot market it to them. Social media has become a place where consumers are more receptive to product messages. The reason why consumers are more receptive to marketing messages on social media is because social media allows for more interaction and marketing of brands from different sides. Social media is a channel that offers a fun and easy way to interact with SME consumers. On social media, SMEs can make connections that match their personalities rather than just sending out direct marketing messages. Social media marketing effectiveness is measured by its ability to deliver sales. Statistical data states that $70 \%$ of sellers acquire new customers through social media. By interacting with potential consumers on a regular basis, it is an effective way to get them to buy the product and turn them into customers. In the field of marketing, Social Media Marketing is the mainstay to carry out promotions at an efficient cost but with maximum results. In the field of business finance, accounting software created specifically for SMEs is a mainstay for managing finances.

The actors in SMEs are referred to as entrepreneurs who have several high self-confidence traits, have the will, always focus on targets, are willing to work hard, and are able to always innovate. The role of SMEs is very important, especially during the Covid-19 virus pandemic. The importance of SMEs is largely related to the backbone of the economy. SMEs allow companies to adapt to a changing environment more easily. Therefore, the existence of SMEs is important as a driving force for entrepreneurship and economic development and to become job creators. Global challenges such as the time of this pandemic certainly bring changes to the life and flow of a business. A good organization is an organization that can see an opportunity, 
big or small, in a situation of uncertainty. Innovation is needed during the current pandemic, namely in SMEs, which is the key to survival. The existence of this innovation is to anticipate every business or group so that the economy in SMEs can continue to advance even though they are experiencing a pandemic and become product quality development. This innovation can transform and build hope to be able to face the impacts that are happening.

There are three types of SMEs innovation, namely: 1. Innovation in a product can be done by creating a new product or service to meet market needs and improve quality. That way it is a process that will increase the profits of SMEs. 2. Innovation in every SMEs process with a new element that refers to increasing the emphasis on detail on the work procedure or service to be produced. 3. SMEs innovation in this administration is related to changes in the method of operating the business effectively which also involves a change by taking advantage of organizational policies, resource allocation, and other factors.

\section{Conclusion}

The results of data analysis have shown that social media marketing has a significant effect on marketing performance, product innovation has a significant effect on marketing performance, market orientation has a significant effect on marketing performance. Based on the results of research and discussion, the implications of this research are that the use of social media has a positive and significant impact on the sustainability of SME business. Theoretically, SME actors can develop insights related to the use of social media, so practically this implies that SME actors are able to increase sales, namely by utilizing social media properly, as a means of promotional activities to maintain business sustainability in the future. SMEs can expand the customer market, digital marketing strategies that can be expanded by using other social media such as Facebook Ads, YouTube, Google Plus, advertising portals on websites or on other digital media so that more consumers will be interested in buying SME products. The use of social media in SMEs can be one of the initial alternatives for business beginners to market products or services because by using social media it can see the traffic from social media users, how many people will visit the business owner's account page and can increase SME business sales.

\section{References}

Affandi, A., Sarwani, A. S., Erlangga, H., Siagian, A. O., Purwanto, A., Effendy, A. A., ... \& Juhaeri, G. (2020). Optimization of MSMEs Empowerment in Facing Competition in the Global Market during the COVID-19 Pandemic Time. Systematic Reviews in Pharmacy, 11(11), 1506-1515.

Aji, P., Nadhila, V., \& Sanny, L. (2020). Effect of social media marketing on Instagram towards purchase intention: Evidence from Indonesia's ready-to-drink tea industry. International Journal of Data and Network Science, 4(2), 91-104.

Djakasaputra, A., Wijaya, O., Utama, A., Yohana, C., Romadhoni, B., \& Fahlevi, M. (2021). Empirical study of Indonesian SMEs sales performance in digital era: The role of quality service and digital marketing. International Journal of Data and Network Science, 5(3), 303-310.

Han, J. K., Kim, N., \& Srivastava, R. K. (1998). Market orientation and organizational performance: is innovation a missing link?. Journal of Marketing, 62(4), 30-45.

Haudi, H., Rahadjengb, E. R., Santamoko, R., Putrac, R. S., Purwoko, D., Nurjannahe, D.,\& Purwanto, A. (2021). The Role of E-Marketing and E-Crm on E-Loyalty of Indonesian Companies During Covid Pandemic and Digital Era. Uncertain Supply Chain Management, 10, 2022.

Hurley, R. F., \& Hult, G. T. M. (1998). Innovation, market orientation, and organizational learning: an integration and empirical examination. Journal of Marketing, 62(3), 42-54.

Kristijono, N., Supratikno, H., Pramono, R., Sudibjo, N., \& Purwanto, A. (2020). Social Media Data Explication to Support Study on Leadership Style for Sustainable Investing. International Journal of Control and Automation, 13(4), 626-657.

Nguyen, B., Yu, X., Melewar, T. C., \& Chen, J. (2015). Brand innovation and social media: Knowledge acquisition from social media, market orientation, and the moderating role of social media strategic capability. Industrial Marketing Management, 51, 11-25.

Prahiawan, W., Fahlevi, M., Juliana, J., Purba, J., \& Tarigan, S. (2021). The role of e-satisfaction, e-word of mouth and etrust on repurchase intention of online shop. International Journal of Data and Network Science, 5(4), 593-600.

Pramono, R., Sondakh, L. W., Bernarto, I., Juliana, J., \& Purwanto, A. (2021). Determinants of the small and medium enterprises progress: A case study of SME entrepreneurs in Manado, Indonesia. The Journal of Asian Finance, Economics, and Business, 8(1), 881-889.

Purba, J., Samuel, S., \& Budiono, S. (2021). Collaboration of digital payment usage decision in COVID-19 pandemic situation: Evidence from Indonesia. International Journal of Data and Network Science, 5(4), 557-568.

Purba, M., Simanjutak, D., Malau, Y., Sholihat, W., \& Ahmadi, E. (2021). The effect of digital marketing and e-commerce on financial performance and business sustaina-bility of MSMEs during COVID-19 pandemic in Indonesia. International Journal of Data and Network Science, 5(3), 275-282.

Purwanto, A. (2021). Partial Least Squares Structural Squation Modeling (PLS-SEM) Analysis for Social and Management Research: A Literature Review. Journal of Industrial Engineering \& Management Research, 2(4), 114 - 123. https://doi.org/10.7777/jiemar.v2i4.168

Purwanto, A., Asbari, M., \& Santoso, T. (2021). Education Management Research Data Analysis: Comparison of Results between Lisrel, Tetrad, GSCA, Amos, SmartPLS, WarpPLS, and SPSS For Small Samples. Nidhomul Haq: Jurnal Manajemen Pendidikan Islam, 6(2), 382-399. https://doi.org/10.31538/ndh.v6i2.1575 
Purwanto, A., Asbari, M., \& Santoso, P. B. (2019). Does Culture, Motivation, Competence, Leadership, Commitment Influence Quality Performance?. Inovbiz: Jurnal Inovasi Bisnis, 7(2), 201-205.

Purwanto, A., Asbari, M., Santoso, T. I., Sunarsi, D., \& Ilham, D. (2021). Education Research Quantitative Analysis for Little Respondents: Comparing of Lisrel, Tetrad, GSCA, Amos, SmartPLS, WarpPLS, and SPSS. Jurnal Studi Dosen Dan Pembelajaran, 4(2), 335-348. https://doi.org/10.30605/jsgp.4.2.2021.1326

Salimi, D., Tavasoli, K., Gilani, E., Jouyandeh, M., \& Sadjadi, S. (2019). The impact of social media on marketing using bibliometrics analysis. International Journal of Data and Network Science, 3(3), 165-184.

Sanny, L., Arina, A., Maulidya, R., \& Pertiwi, R. (2020). Purchase intention on Indonesia male's skin care by social media marketing effect towards brand image and brand trust. Management Science Letters, 10(10), 2139-2146.

Shaher, A., \& Ali, K. (2020). The effect of entrepreneurial orientation and knowledge management on innovation performance: The mediation role of market orientation. Management Science Letters, 10(15), 3723-3734.

Thongsri, N., \& Chang, A. K. H. (2019). Interactions among factors influencing product innovation and innovation behaviour: Market orientation, managerial ties, and government support. Sustainability, 11(10), 2793.

Wijaya, O., Sulistiyanib, S., Pudjowatic, J., Kurniasih, N., \& Purwanto, A. (2021). The role of social media marketing, entertainment, customization, trendiness, interaction and word-of-mouth on purchase intention: An empirical study from Indonesian smartphone consumers. International Journal of Data and Network Science, 5(3), 231-238.

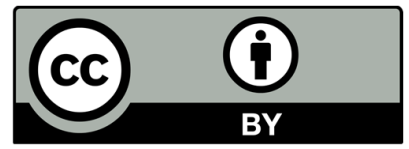

(C) 2022 by the authors; licensee Growing Science, Canada. This is an open access article distributed under the terms and conditions of the Creative Commons Attribution (CC-BY) license (http://creativecommons.org/licenses/by/4.0/). 